Meta

Journal des traducteurs

Translators' Journal

\title{
In Memoriam - Emilio Ortega Arjonilla
}

\section{África Vidal}

Volume 64, numéro 2, août 2019

URI : https://id.erudit.org/iderudit/1068194ar

DOI : https://doi.org/10.7202/1068194ar

Aller au sommaire du numéro

Éditeur(s)

Les Presses de l’Université de Montréal

\section{ISSN}

0026-0452 (imprimé)

1492-1421 (numérique)

Découvrir la revue

Citer ce document

Vidal, Á. (2019). In Memoriam - Emilio Ortega Arjonilla. Meta, 64(2), 305-306. https://doi.org/10.7202/1068194ar d'utilisation que vous pouvez consulter en ligne.

https://apropos.erudit.org/fr/usagers/politique-dutilisation/ 


\section{In Memoriam - Emilio Ortega Arjonilla}

Los estudios de traducción e interpretación se establecieron en España como disciplina universitaria hace algo más de 25 años. Quienes fuimos testigos del nacimiento de las facultades y departamentos que hoy nos acogen tenemos edades parecidas y hemos ido sorteando las dificultades y saboreando las mieles de lo que tanto costó instaurar y que ahora parece ya asentado.

Por eso me resulta tan complicado separar lo académico e institucional de lo personal al recordar a uno de los nombres que estuvo desde el principio apoyando la disciplina, fomentando congresos, creando colecciones en editoriales de prestigio, como es Comares, donde prácticamente todos hemos publicado. Emilio Ortega Arjonilla se ha ido, pero es (en presente) una de esas figuras que será siempre (en futuro) un referente en los estudios de traducción en España. Su compromiso con nuestra área de conocimiento fue firme y decidido, y, gracias a su extraordinaria capacidad de trabajo, su entusiasmo y su pasión constantes, su huella quedará impresa en ámbitos tan dispares como la filosofía, la traducción jurídica, médica o científicotécnica. Estuvo presente allí donde se emprendía una nueva andadura, hizo oír su voz en encuentros y asambleas, discrepando a veces y apoyando otras, pero con el espíritu constructivo que le caracterizaba, permanentemente dispuesto a trabajar sin descanso, porque ese fue sin duda su rasgo más característico.

T.S. Eliot se preguntó una vez en uno de sus poemas dónde está la vida que hemos perdido en vivir. Emilio nos ha dejado la suya entre las líneas traducidas, en sus libros, en sus congresos, porque no se ha ido, porque la aniquiladora idea de no ser no va a poder con su incontenible afán por vivir, pues, como asegura Mario Benedetti, sus huellas serán siempre de ida y vuelta, trazos a lo largo de un camino que dibujó con sus cavilaciones.

La muerte es, sin duda, nuestra certeza más fehaciente; es esa mano silente que, como bien dice Vicente Aleixandre, acaba llegando hasta nuestras venas. Pero su triunfo resulta parcial, en tanto su aparición es también la prueba inequívoca de que hubo vida, y tanto más en el caso de una existencia tan llena como la de quien (no) se ha ido para aventar otros parajes, donde sin duda seguirá siendo maestro en bonhomía.

$\mathrm{Y}$ es que, ante un legado tan vital como el de Emilio Ortega Arjonilla, nos preguntamos con John Donne en el decimo ${ }^{1}$ de sus Holy Sonnets dónde está esa supuesta victoria de la muerte:

Death, be not proud, though some have called thee

Mighty and dreadful, for thou art not so; 
306 MeTA, LXIV, 2, 2019

For those whom thou think'st thou dost overthrow

Die not, poor Death, nor yet canst thou kill me.

ÁFrICA VIDAL

Universidad de Salamanca, Salamanca, España

\section{NOTES}

1. Donne, John (1633/2005): Sonnet X (Death Be Not Proud). In: Gary A. STringer, ed. The Variorum Edition of the Poetry of John Donne. Vol. 7. Part. 1. Bloomington/Indianapolis: Indiana University Press, 10. 